TÄ̈ CHÍ PHAÙ TRIEÂ KH\&CN, TÄ̈ 16, SOÁK1- 2013

\title{
RESISTANCE SWITCHING BEHAVIOR OF ZnO THIN FILMS FOR RANDOM ACCESS MEMORY APPLICATIONS
}

\author{
Trung Do Nguyen ${ }^{(1)}$, Van Thuy Dao(2), Kim Ngoc Pham ${ }^{(1)}$, Thi Kieu Hanh Ta ${ }^{(1)}$, Tran Le ${ }^{(1)}$, Tuan \\ Tran $^{(1)}$, Van Hieu Le ${ }^{(1)}$, Jaichan Lee ${ }^{(3)}$, Mau Chien Dang ${ }^{(4)}$, Bach Thang Phan ${ }^{(1)}$ \\ (1) University of Science, VNU-HCM \\ (2) TrungVuongHigh SchoolTp. HCM \\ (3) Sungkyunkwan University, South Korea \\ (4) Laboratory for Nanotechnology, VNU-HCM \\ ((Manuscript Received on April $5^{\text {th }}, 2012$, Manuscript Revised May $\left.15^{\text {th }}, 2013\right)$
}

ABSTRACT: We investigated resistance switching behavior of the Ag/ZnO/Ti structures for random access memory devices. These films were prepared on glass substrate by dc sputtering technique at room temperature. The resistance switching follows unipolar switching mode with small switching voltages $(0.4 \mathrm{~V}-0.6 \mathrm{~V})$. Our results figured out that the Ag/ZnO/Ti/Glass structure is a candidate structure for nonvolatile data storage applications.

Keywords: Resistance switching, random access memory, sputtering, ZnO

\section{INTRODUCTION}

Resistance random access memory (ReRAM) has attracted extensive attention for their applications to nonvolatile data storage technologies due to its simple structure, low power consumption, low cost, nonvolality and high speed performance [1-12]. The resistance switching was observed from various materials, such as perovskite oxides $\left(\operatorname{Pr}_{0.7} \mathrm{Ca}_{0.3} \mathrm{MnO}_{3}\right.$, $\mathrm{La}_{0.7} \mathrm{Ca}_{0.3} \mathrm{MnO}_{3}$, Cr-doped $\mathrm{SrZrO}_{3}, \mathrm{Cr}$-doped $\left.\mathrm{SrTiO}_{3} \ldots\right)$ [1-9], transition metal oxides (NiO, Ti, $\left.\mathrm{CuO}, \quad \mathrm{ZrO}_{2}, \quad \mathrm{ZnO} \ldots\right) \ldots[10-12] . \quad$ The resistance switching effect is regarded as memory effect. The memory effect can be observed from the current - voltage characteristics of metal - insulator - metal structure (MIM), in which resistance of the
MIM structure reversely changes between the high resistance state (HRS) and the low resistance state (LRS), corresponding to logic signal (off and on states or 0 and 1 states). Two switching modes, unipolar switching and bipolar switching, have been observed to describe the switching between HRS and LRS. Although the resistance switching effect can be obtained in various materials, the origin of resistance switching is controversial. The clear explanation of resistance switching in various materials is the challenge and motivation for current research. We have already published our research on the resistance switching effect in $\mathrm{Pt} / \mathrm{Cr}$-doped $\mathrm{SrTiO}_{3} / \mathrm{La}_{0.5} \mathrm{Sr}_{0.5} \mathrm{CoO}_{3}$ structure [5-9]. In this study, we reported resistance switching behavior in the $\mathrm{Ag} / \mathrm{ZnO} / \mathrm{Ti}$ 
structure for nonvolatile data storage applications.

\section{EXPERIMENTS}

The $\mathrm{Ag} / \mathrm{ZnO} / \mathrm{Ti} / \mathrm{Glass}$ structure was fabricated by sputtering technique at room temperature, $\mathrm{ZnO}$ thin film was sandwiched between top ( $\mathrm{Ag}$ ) and bottom (Ti) electrode materials. A 150 nm-thick metallic Ti layer was deposited on a commercial glass substrate in $\mathrm{Ar}$ gas ambient of $6 \times 10^{-3}$ Torr, depositing current $\mathrm{I}_{\mathrm{Ti}}=1 \mathrm{~A}$, while the 100 nm-thick $\mathrm{ZnO}$ layer was deposited in $\mathrm{Ar}+\mathrm{O}_{2}\left(\mathrm{Ar} / \mathrm{O}_{2}=1\right)$ mixed gas ambient of $6 \times 10^{-3}$ Torr, depositing current $\mathrm{I}_{\mathrm{ZnO}}=0.3 \mathrm{~A}$. The Ag top electrode of $75 \mathrm{~nm}$-thick was deposited on the $\mathrm{ZnO}$ thin film in Ar gas ambient of $6 \times 10^{-3}$ Torr, depositing current $\mathrm{I}_{\mathrm{Ag}}=0.15 \mathrm{~A}$. During the deposition of Ag layer, a mask was used for top electrode patterning. The size of $\mathrm{Ag}$ top electrode is $1 \mathrm{~mm}$ in diameter. Current-voltage (I-V) measurements were carried out using a Keithley 2400 source meter. During the electrical measurement, the positive sweep voltage is applied to the Ag top electrode, while the Ti bottom electrode is grounded. The thickness of these films was determined by Dektak 6M Stylus Surface Profilometer. The crystalline phases of the thin films were characterized in $\theta-2 \theta$ mode by D8 Advance (Bruker) x-ray diffractometer (XRD) with $\mathrm{Cu}$ $\mathrm{K} \alpha$ radiation $(\lambda=0.154 \mathrm{~nm})$. The depositing process and crystalline analysis will be presented elsewhere.

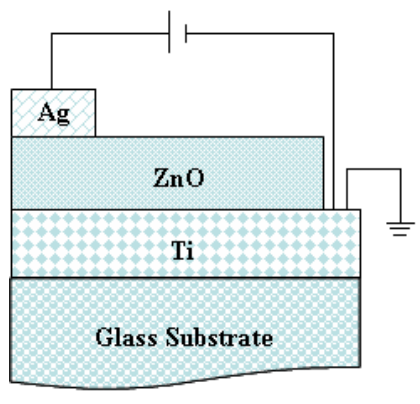

Figure 1. Schematic diagram of the $\mathrm{Ag} / \mathrm{ZnO} / \mathrm{Ti}$ structure

\section{RESULTS AND DISCUSSION}

As-prepared $\mathrm{Ag} / \mathrm{ZnO} / \mathrm{Ti} / \mathrm{Glass}$ structures were initially in a high resistance state (HRS). To find out the switching voltages, we increased sequently the largest sweeping voltage $\mathrm{V}_{\operatorname{maz}}\left(\mathrm{V}_{\max }=0.1 \mathrm{~V}, 0.15 \mathrm{~V}, 0.2 \mathrm{~V} \ldots\right)$ to observe the set process. Compliance current of $100 \mathrm{~mA}$ was applied to prevent permanent structure breakdown. Figure 2 shows the I-V characteristics of the set and the reset process. In the 0 to $0.45 \mathrm{~V}$ sweeping, corresponding to the black line $\left(\mathrm{V}_{\max }=0.45 \mathrm{~V}\right)$, a sudden current increase (resistance decrease) from HRS to low resistance state (LRS), was observed at about $\mathrm{V}_{\mathrm{SET}} \sim 0.42 \mathrm{~V}$, the LRS remained until the end of the sweeping. This sweeping switched the structure into LRS, corresponding to "set" process.

\section{Trang 82}




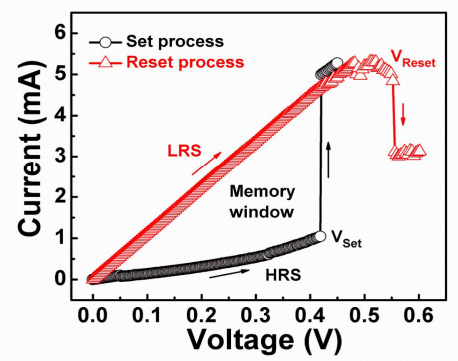

Figure 2. I-V characteristics of the set and Reset process.

The $\mathrm{Ag} / \mathrm{ZnO} / \mathrm{Ti} / \mathrm{Glass}$ structure now is in LRS. The next sweeping process from 0 to $\mathrm{V}_{\max }(0.1 \mathrm{~V}, 0.15 \mathrm{~V}, 0.2 \mathrm{~V} \ldots .$.$) was applied to$ the structure to observe the reset process, corresponding to a red line. The I-V characteristic in this process is different from that in the set process above ( 0 to $0.45 \mathrm{~V})$. The value of current of the reset process is higher than the current value of the set process measured at the same voltage. In the 0 to $0.6 \mathrm{~V}$ sweeping process, current increased linearly with sweeping voltage until $0.51 \mathrm{~V}$, then current gradually decreased. An abrupt drop of current could be observed at voltage of $0.55 \mathrm{~V}$ $\left(\mathrm{V}_{\text {RESET }} \sim 0.55 \mathrm{~V}\right)$, the structure switched back to HRS.

The set and reset process correspond to the "write" and "erase" data in storaging device. We can observe the memory effect or memory window (two current values at a certain voltage) in the voltages below $\mathrm{V}_{\mathrm{SET}}$. The I-V curve with a triangle shape is visible, similar to the model of memristive system analyzed by Srtukov et al [13]. The resistance switching is in unipolar mode, the switching between HRS and LRS only depends on magnitude of sweeping voltage, not polarity. In the following sweeping, the unipolar resistance switching could be observed repeatedly. In these sweeping, a small dispersion in the value of switching voltage was found along with a visible and non-overlapped memory window, which are important for nonvolatile memory applications.

The two above experiments figured out the set voltage and reset voltage. To observe the resistance switching (HRS $\rightarrow$ LRS and LRS $\rightarrow$ HRS) in one sweeping process, we applied the 0 to $0.6 \mathrm{~V}$ sweeping. Figure 3 shows the $\mathrm{I}-\mathrm{V}$ characteristics of $\mathrm{Ag} / \mathrm{ZnO} / \mathrm{Ti} / \mathrm{Glass}$ structures in the 0 to $0.6 \mathrm{~V}$ sweeping. The $\mathrm{Ag} / \mathrm{ZnO} / \mathrm{Ti} / \mathrm{Glass}$ structure was now in a HRS. Similar to these two above experiments, we observed the two resistance switchings in the range of $0.4-0.6 \mathrm{~V}$, HRS $\rightarrow$ LRS at $0.42 \mathrm{~V}$ and HRS $\rightarrow$ LRS at $0.55 \mathrm{~V}$. The small switching voltages are suitable for electronic device applications.

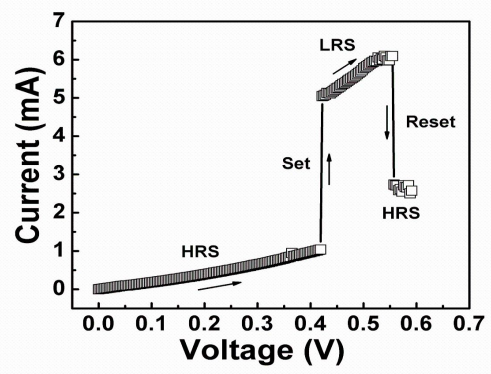

Figure 3. $\mathrm{I}-\mathrm{V}$ characteristics of the $\mathrm{Ag} / \mathrm{ZnO} / \mathrm{Ti}$ structure in the 0 to $0.6 \mathrm{~V}$ sweeping

Figure 4 show the current evolution of the HRS and LRS within 10 switching cycles. The current values were read out at $0.25 \mathrm{~V}$ in each 
sweep. The values of HRS show a small fluctuant, while the values of LRS fluctuate in large range. The current ratio of HRS and LRS is above 5, which is lower than the reported value of 10 in some published results $[10,12]$. In order to increase the ratio, the effect of the depositing oxygen pressure of $\mathrm{ZnO}$ thin films on the ratio switching is underdoing.

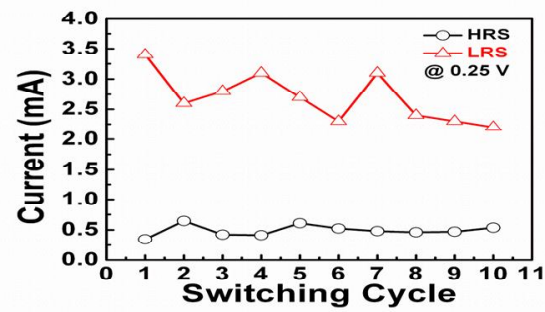

Figure 4. Memory window of the $\mathrm{Ag} / \mathrm{ZnO} / \mathrm{Ti}$ structure

\section{CONCLUTIONS}

The $\mathrm{Ag} / \mathrm{ZnO} / \mathrm{Ti}$ structures were prepared on glass substrate by dc sputtering technique. The resistance switching behavior of the $\mathrm{Ag} / \mathrm{ZnO} / \mathrm{Ti} / \mathrm{Glass}$ structure was demonstrated. The resistance switching follows unipolar switching mode, the resistance switching depends on magnitude of external electric field but not on polarity. The small switching voltages figured out that the $\mathrm{Ag} / \mathrm{ZnO} / \mathrm{Ti} / \mathrm{Glass}$ structure is a candidate structure for nonvolatile data storage applications.

\title{
ĐặC TRƯNG ĐẢO ĐIỆN TRỞ CỦA MÀNG MỎNG ZnO ÚNG DỤNG TRONG Bộ NHỚ TRUY CẬP NGÃ̃U NHIÊN
}

\author{
Nguyễn Trung Đọ̣ ${ }^{(1)}$, Đào Vân Thúy ${ }^{(2)}$, Phạm Kim $\operatorname{Ngọc}^{(1)}$, Tạ Thị Kiều Hạnh ${ }^{(1)}$, Lê Trấn ${ }^{(1)}$, Trần \\ Tuấn ${ }^{(1)}$, Lê Văn Hiếu ${ }^{(1)}$, Lee Jaichan ${ }^{(3)}$, Đặng Mậu Chiến ${ }^{(4)}$, Phan Bách Thắng ${ }^{(1)}$ \\ (1)Trường Đại học Khoa học Tự nhiên, VNU-HCM \\ (2) Trường Phổ thông Trung học Trưng Vương Tp.HCM \\ (3) Trường Công nghệ và Khoa học Vật liệu tiên tiến, Đại học Sungkyunkwan, Hàn Quốc
}

(4) Phòng thí nghiệm Công nghệ Nano, VNU-HCM

Tóm tắt: Chúng tôi đã khảo sát đặc trung thay đổi điện trở của cấu trúc vật liệu $A g / Z n O / T i$ nhằm úng dụng trong bộ nhớ truy cập ngẫu nhiên. Các màng mỏng trong cấu trúc trên được chế tạo bằng phuơng pháp phún xạ dc tại nhiệt độ phòng. Đặc trung đảo điện trở của màng mỏng ZnO tuân theo dạng đơn cực với thế đảo điện trở có giá trị tùu $0.4 \mathrm{~V}-0.6 \mathrm{~V}$. Kết quả thu được chứng tỏ rằng cấu trúc vật liệu $\mathrm{Ag} / \mathrm{ZnO} / \mathrm{Ti}$ có thể úng dụng trong thiết bị luu trũ dũ liệu không khả biến.

Tù khóa: Đảo điện trở, Bộ nhớ truy cập ngẫu nhiên, Phún xạ, Màng mỏng ZnO 


\section{REFERENCES}

[1]. C. Rossel, G.I. Meijer, D. Bremaud, D. Widmer, Electrical conduction distribution across metal - insulator - metal structure during bistable switching, J. Appl. Phys. 90, 2892 (2001).

[2]. G. Meijer, I.U. Staub, M. Janousch, S.L. Johnson, B. Delley and T. Neisius, Valence states of $\mathrm{Cr}$ and the insulator - to - metal transition in Cr-doped $\mathrm{SrTiO}_{3}$, Phys. Rev. B 72, 155102 (2005).

[3]. A. Odagawa, H. Sato, I.H. Inoue, H. Akoh,H. Kawasaki, M.Y. Tokura, T. Kanno, H. Adachi, Colossal electroresistance of a $\mathrm{Pr}_{0.7} \mathrm{Ca}_{0.3} \mathrm{MnO}_{3}$ at room temperature, Phys. Rev. B 70, 224403 (2004).

[4]. A. Sawa, T. Fujii, M. Kawasaki, Y. Tokura, Interface resistance switching at a few nanometer thick perovskite manganite active layers,Appl. Phys. Lett. 88, 232112 (2006).

[5]. B. T. Phan, T. Choi, and J. Lee, TrapControlled Space - Charge - Limited Current Conduction in the $\mathrm{Cr}$ - doped $\mathrm{SrTiO}_{3}$ Thin Films Deposited by Using Pulsed Laser Deposition,J. Korean Phys. Soc. 51, 664 (2007).

[6]. B. T. Phan, T. Choi, J. Lee, Impedance Spectroscopy Study on Trap-Controlled Space-Charge-Limited Conduction of $\mathrm{Cr}$ doped $\mathrm{SrTiO}_{3}$ Thin Films, Integrated Ferroelectrics 96, 146 (2008).
[7]. B. T. Phan, J. Lee, Effects of Interfacial Oxygen Efficient Layer on Resistance Switching in Cr-doped $\mathrm{SrTiO}_{3}$ Thin Films, Appl. Phys. Lett. 93, 222906 (2008).

[8]. B. T. Phan, N. C. Kim, J. Lee, Ac Conductivity of Cr-doped $\mathrm{SrTiO}_{3}$ Thin Films, J. Korean Phys. Soc. 54, 873 (2009).

[9]. B. T. Phan, J. Lee, Non-adiabatic small polaron tunneling conduction in reduced $\mathrm{Cr}$-doped $\mathrm{SrTiO}_{3 \text {-delta }}$ Thin Films, Appl. Phys. Lett. 94, 232102 (2009).

[10]. Shibing Long, Qi Liu, Hangbing Lv, Yingtao Li, YanWang, Sen Zhang, Wentai Lian, Kangwei Zhang, MingWang, Hongwei Xie, Ming Liu, Resistive switching mechanism of $\mathrm{Ag} / \mathrm{ZrO}{ }_{2}: \mathrm{Cu} / \mathrm{Pt}$ memory cell, Appl. Phys. A. 102, 915 (2011).

[11]. Young Ho Do, June Sik Kwak and Jin Pyo Hong, Hyunsik Im, Bae Ho Park, Nonvolatile Unipolar and Bipolar Resistive Switching Characteristics in Codoped $\mathrm{TiO}_{2}$ Thin Films with Different Compliance Currents, J. Korean Phys. Soc. 5, 1009 (2009).

[12]. Xinman Chen, Guangheng $\mathrm{Wu}$, and Dinghua Bao, Resistive switching behavior of $\mathrm{Pt} / \mathrm{Mg}_{0.2} \mathrm{Zn}_{0.8} \mathrm{O} / \mathrm{Pt}$ devices for nonvolatile memory applications, Appl. Phys. Lett. 93, 093501 (2008).

[13]. D. B. Strukov, G. S. Snider, D. R. Stewart, R. S. Williams, The missing memristor found, Nature, London, 453, 80 (2008). 